\title{
Finger Millet (Eleusine coracana G.) based Intercropping for Food Security in Konkan Region -A Review
}

\author{
S.B. Bhagat, A.V. Dahiphale*, N.V. Mhaskar, D.G. Jondhale and M.C. Puri \\ Dr. Balasaheb Sawant Konkan Krishi Vidyapeeth, Dapoli-415 712, \\ Dist. Ratnagiri (Maharashtra), India \\ *Corresponding author
}

\section{A B S T R A C T}

\begin{tabular}{|c|c|}
\hline $\begin{array}{l}\text { Ke y w o r d s } \\
\text { Eleusine coracana, } \\
\text { Intercropping, } \\
\text { Food security }\end{array}$ & $\begin{array}{l}\text { Since major cereals which are grown on good solls supplied with large quantity of } \\
\text { fertilizer, irrigation and pesticide inputs have attained yield plateau. Millets have } \\
\text { potentiality of contributing to increase food production, both in developing and developed } \\
\text { countries. In general, millets are rich in many minerals besides their better adaptability to } \\
\text { adverse growing conditions. Millets are cultivated mainly as rainfed crop. However, these }\end{array}$ \\
\hline Article Info & situation where other crops fail to produce an acceptable harvest. Among different millets \\
\hline $\begin{array}{l}\text { Accepted: } \\
\text { 26 December } 2018 \\
\text { Available Online: } \\
10 \text { January } 2019\end{array}$ & $\begin{array}{l}\text { considered as poor man's food and also recommended as the food for person suffering } \\
\text { from diabetes due to its medicinal value. For assessment of intercropping (two crops only), } \\
\text { sole cropping by giving different formulae this paper give the critical review the Finger }\end{array}$ \\
\hline & based intercropping for food secur \\
\hline
\end{tabular}

\section{Introduction}

In recent years, there has been increasing recognition of the importance of millets in India, since major cereals which are grown on good soils supplied with large quantity of fertilizer, irrigation and pesticide inputs have attained yield plateau. Millets have potentiality of contributing to increase food production, both in developing and developed countries (Shau, 1965). In general, millets are rich in many minerals besides their better adaptability to adverse growing conditions.
Millets are cultivated mainly as rainfed crop. However, these are especially valued for filling specific niches because they often succeed under stressful situation where other crops fail to produce an acceptable harvest. Among different millets finger millet has capacity to produce consistent yield, even without special care. It is considered as poor man's food and also recommended as the food for person suffering from diabetes due to its medicinal value. Finger millet has some unique qualities, which make it potentially valuable product. The straw has an immense 
utility as fodder for both draught and milch animals. It makes good fodder and contains up to $61 \%$ total digestible nutrients (Upadhyaya, 2006). Nutritional value of finger millet implies proteins $7.6 \mathrm{~g}$, fats $1.5 \mathrm{~g}$, carbohydrates $88 \mathrm{~g}$, calcium $370 \mathrm{mg}$, vitamin A $0.48 \mathrm{mg}$, thiamine (B1) $0.33 \mathrm{mg}$, riboflavin (B2) $0.11 \mathrm{mg}$ and niacin (B3) $1.2 \mathrm{mg}$ per $100 \mathrm{~g}$ of grains.

In Maharashtra, finger millet occupies an area of about 120 thousand hectares with an annual grain production of 109 thousand tonnes with productivity $908 \mathrm{~kg}$ per ha in 2009-10 (Rajendra Prasad, 2012).

It is mainly cultivated in Thane, Raigad, Ratnagiri, Sindhudurg, Dhule, Jalgaon, Nashik, Pune, Satara and Kolhapur districts of Maharashtra. The largest acreage of ragi is in Konkan region. It is also taken as rabi crop where irrigation facilities are available. In Konkan region, finger millet plays an important role in agriculture with an area of 471 hundred ha with an annual production of 480 hundred tonnes (Deshmukh, 2007).

Intercropping is one of the sure ways of increasing production without much increase in the application of inputs. Intercropping refers to growing of two or more crops simultaneously on the same piece of land. This system gives crop intensification of both time and space. Apart from its advantages like diversification, labors distribution, maintenance of soil fertility, suppression of weeds, two major advantages are higher productivity and greater stability through utilization of solar energy, moisture and nutrients. The practice of intercropping in finger millet will definitely improve the economy of lower class as it will help them in fulfilling their own requirements along with finger millet which they grow on large scale. Intercropping of finger millet with pigeon pea at 4:1 ratio resulted in to higher finger millet equivalent yield compared to sole finger millet (Ved Prakash et al., 2005). Legumes have assumed much significance in intercropping because of their potential for nitrogen transfer to cereal crop (Giri and De, 1978). Growing groundnut as an intercrop in finger millet is more profitable than sole finger millet in Konkan region during kharif season (Thorat et al., 1986).

\section{Assessment of intercropping indices}

For assessment of intercropping (two crops only), different indices have been used to determine advantage of an intercropping system over sole cropping by giving different formulae.

Descriptions of all such indices along with their formulae, advantage and disadvantage are presented.

The following symbols have been used in the formulae of these indices

$Y_{i i}$ - Sole crop (pure stand) yield of crop A.

$Y_{j j}$ - Sole crop (pure stand) yield of crop B.

$Y_{i j^{-}}$Intercrop yield of crop $\mathrm{A}$, when grown with crop B as intercrop.

$Y_{j i}$-Intercrop yield of crop B, when grown with crop A as intercrop.

$a_{i j}$ - Proportion of area allotted to crop $\mathrm{A}$ in intercropping.

$a_{j i}$ - Proportion of area allotted to crop B in intercropping.

$P_{i^{-}}$Unit price of crop A.

$P_{j^{-}}$Unit price of crop B.

\section{Relative Crowding Coefficient (RCC)}

This coefficient was proposed by De wilt (1960) and examined by Hall (1974a, 1974b). The RCC is useful for replacement series of intercropping experiment. RCC for each crop gives a measure of whether that crop was produced more or less yield than expected yield, e.g. RCC for crop A is 
Intercrop yield of crop A x Proportion of area under crop $\mathrm{B}$ in intercropping

$K_{i j}=$

(Yield of sole crop A - Intercrop yield of crop A) $x$ (Proportion of area under crop

A in intercropping)

$K_{i j}=\mid$\begin{tabular}{l|}
$Y_{i j} a_{i j}$ \\
\cline { 1 - 2 } \\
$\left(y_{\mathrm{ii}}-y_{i j) \times} a_{i j}\right.$
\end{tabular}

If $\mathrm{k}_{i j}>1$, then there is yield advantage of crop $\mathrm{A}$ in intercropping. If there is no effect of intercropping on the yield of crop $\mathrm{A}$, then $\mathrm{k}_{i j}=$ $1 ; \mathrm{k}_{i j}<1$ indicates the yield disadvantages due to intercropping. Similarly, one can compute $\mathrm{k}_{j i}$, RCC for crop B. The component crop with higher relative crowding coefficient is the dominant and is more competitive than the associated crop.

\section{Land Equivalent Ratio (LER)}

\begin{tabular}{|l|l|l|l|}
\hline \multirow{2}{*}{$A_{i j}=$} & $Y_{i j}$ & & $Y_{j i}$ \\
& $Y_{i i} \cdot a_{i j}$ & & $Y_{j j} \cdot a_{j i}$ \\
\hline
\end{tabular}

Willy and Osiru(1972) defined LER as relative area of the some crop that would be required to produce the equivalent yield achieved by intercropping and given by

\begin{tabular}{|l|l|l|l|l|}
\hline \multirow{2}{*}{$\mathrm{LER}=$} & $\mathrm{Y}_{\mathrm{ij}}$ & & $\mathrm{Y}_{\mathrm{ji}}$ & \\
& $\mathrm{Y}_{\mathrm{ii}}$ & & & $\mathrm{L}_{\mathrm{i}}+\mathrm{L}_{\mathrm{j}}$ \\
& & & \\
\hline
\end{tabular}

Where, $\mathrm{L}_{\mathrm{i}}$ and $\mathrm{L}_{\mathrm{j}}$ are known as component LER or partial LERs.

\section{Crop Equivalent Yield (CEY)}

Lal and Ray (1976), Verma and Modgal (1983) proposed economics of crop by converting grain/seed/fodder etc. in terms of gross return for valid comparison and obtained wheat equivalent yield as
Where, $\mathrm{C}_{\mathrm{i}}=\mathrm{Pc}_{\mathrm{i}} / \mathrm{P}_{\mathrm{w}}$

$\mathrm{Pc}_{\mathrm{i}}$ and $\mathrm{Pw}$ are per unit prices of $\mathrm{i}^{\text {th }}$ crop and wheat, respectively.

\section{Aggressivity (A)}

Aggressivity was proposed by Mc Gillchrist and Trenbath (1971), who extended the work of William (1962) and Mc Gillchrist (1965). Aggressivity of crop A with crop B gives the simple difference between the expected relative yield only. Aggressivity of crop A with crop B is given by

$\mathrm{A}_{\mathrm{ij}}=$

Intercrop yield of crop A Intercrop yield of crop B

Expected yield of crop A Expected yield of crop B

$=$ Expected relative yield of crop A Expected relative yield of crop B

If the aggressivity value of a component crop with other component crop is zero, then the two component crops are said to be equally competitive. Aggressivity value when greater than zero indicates that one crop is dominating over the other. As it is based on a sample difference, the interpretation of intercropping treatment may become difficult if the values are identical in different treatments.

\section{Area Time Equivalent Ratio (ATER)}

Jagannath and Sunderaja (1987) proposed Area Time Equivalent Ratio

ATER $=($ Li.ti + Lj.tj $) / T$

Where, $\mathrm{Li}$ and $\mathrm{Lj}$ - Partial LERs ti and t $j$ duration of crop $i$ and $j$ $\mathrm{T}=$ Duration of whole intercropping system ATER> 1 = intercropping system more advantageous than monocropping 


\section{Yield advantage in intercropping system}

\section{Land Equivalent Ratio (LER)}

Pradhan and Ghosh, (1988) at Ranchi (Jharkhand) obtained higher LER (1.51) under finger millet + black gram mixed cropping system as compared to finger millet + green gram (1.14) mixed cropping system and that of sole crop (1.00). The higher LER was recorded under finger millet (cv. EC.423-4) + pigeon pea (cv.T-21) paired row system as compared to finger millet (cv. PR$717)+$ pigeon pea (cv.Kanke-9) paired row system and that of sole crop at Bhubaneswar, Orissa (Parida et al., (1989). Jadhav et al., (1992) from Dapoli reported that finger millet and okra 4:2 intercropping system recorded higher LER as compared to finger millet + urd bean 4:2, finger millet + groundnut $4: 2$ and finger millet + cowpea 4:2. At Nagamangala (Karnataka), higher LER was recorded under finger millet + pigeon pea 8:2 intercropping as compared to finger millet + field bean 8:2 intercropping system and sole crop of finger millet (Shankaralingappa and Hegde 1992). Shankaralingappa and Rajashekara (1992) from Bangalore reported that intercropping of finger millet with Lucerne 1:1 recorded higher LER as compared to that of finger millet + field bean 1:1 intercropping system and sole crop of finger millet.

Itnal et al., (1994) observed that, the LER was highest (1.41) in intercropping of pearl millet + pigeon pea in row proportion of 4:2 with additive series followed by the same plant density series in 3:1 row proportion (1.36). Das and Guha (1996) found that land equivalent ratio in all intercropping treatments were higher than pure crop. The highest land equivalent ratio (1.30) was given by row ratio 2:2 of rape seed + niger. Dubey and Shrivas (1997) observed that intercropping of kodo millet + pigeon pea $(4: 1)$ gave the highest seed yield of $793 \mathrm{~kg} \mathrm{ha}^{-1}$ after sole kodo millet $1226 \mathrm{~kg} \mathrm{ha}^{-1}$ during all the years and also the highest kodo millet seed equivalent yield of $2961 \mathrm{~kg} \mathrm{ha}^{-1}$ was recorded in kodo millet + pigeon pea $2: 1$ proportion.

On red sandy loam soil at Koraput (Orissa), Mohapatra and Halder (1998) obtained higher LER under finger millet + soybean 5:2 intercropping system as compared to that of $3: 2$ row ratio, finger millet + rice bean $(5: 2$ and 3:2 row ratio) intercropping system and sole crop of finger millet. Singh and Arya (1999) at Ranichauri (Uttranchal) observed that finger millet and soybean mixed cropping system (9:1 seed mixture) recorded higher LER (1.35) as compared to finger millet + rice bean (1.21) and finger millet + rajma mixed cropping system and sole crop of finger millet. Finger millet + pigeon pea at 4:1 ratio recorded the highest land equivalent ratio (1.48) for two years indicating 48 per cent more land use efficiency over the sole cropping. Maitra et al., (2001) and Sarangi et al., (2002) from Berhampur recorded higher LER under intercropping of finger millet (medium duration) with pigeon pea (short duration) (8:2) as compared to finger millet (medium duration) + pigeon pea (medium duration) (8:2) intercropping system and sole crop of finger millet. Ramamoorthy et al., (2003a) at Coimbatore (TN) reported that finger millet + determinant type of field bean intercropping recorded higher LER (1.48) as compared to finger millet + field bean (indeterminant type)intercropping system in 8:2 row ratio LER (1.45) and sole crop of finger millet LER (1.00). Finger millet + french bean intercropping recorded higher LER as compared to finger millet + horse gram and was on par with those of finger millet intercropped with peas, soybean, cluster bean (Girish, 2004). Padhi et al., (2010) reported that intercropping system of pigeon pea (UPAS -120) + finger millet (Bhairabi) at 2:4 row ratio recorded higher 
LER (1.42) as compared to pigeon pea (UPAS- 120) + finger millet (PR- 202) in 2:4 row ratio. The literature on land equivalent ratio (LER) clearly indicated that finger millet intercropped with pigeon pea or soybean or groundnut recorded higher LER than finger millet intercropped with green gram, rajma, rice bean or field bean. Further, LER value was higher under inter/mixed cropping system than sole cropping of finger millet.

\section{Crop equivalent yield}

Experiment conducted at Dapoli showed higher finger millet equivalent yield under finger millet + okra 4:2 intercropping system as compared to finger millet + urd bean $4: 2$, finger millet + groundnut $4: 2$ and finger millet + cow pea 4:2 (Jadhav et al., 1992). At Bangalore, highest FMEY was obtained under finger millet + pigeon pea intercropping system in 8:2 row ratio as compared to finger millet + field bean intercropping system in 8:2 row ratio and sole crop of finger millet (Shankaralingappa and Hedge, 1992). Shivkumar and Yadahalli (1995) at Bangalore, reported that intercropping of pigeon pea with finger millet in 5:2 row ratio gave higher FMEY as compared to that of finger millet + field bean 5:2 intercropping system and sole crop of finger millet. Experiment conducted at Ranichauri (Uttaranchal) showed higher finger millet equivalent yield under finger millet + soybean mixed cropping system (9:1 seed mixture) as compared to finger millet + rice bean and finger millet + rajma mixed cropping system (9:1 seed ratio) and sole crop of finger millet (Singh and Arya, 1999). Jena et al., (2000) at Ganjam (Orissa) reported that intercropping of finger millet with pigeon pea in 4:1 row proportion recorded higher FMEY as compared to 5:2 row ratio and sole crop of finger millet. Shashidhara et al., (2000) from Hanumanamatti, Karnataka reported that finger millet + pigeon pea in $4: 2$ row ratio recorded the higher FMEY $16.63 \mathrm{q} \mathrm{ha}^{-1}$ as compared to those of $3: 1\left(14.86 \mathrm{q} \mathrm{ha}^{-1}\right)$ and 5:1 (15.27 $\left.\mathrm{q} \mathrm{ha}^{-1}\right)$ row ratio and sole crop of finger millet.

Ramamoorthy et al., (2003) conducted field experiment at Coimbatore and observed that intercropping of finger millet + field bean (determinant type) in 8:2 row ratio recorded higher FMEY of $4516 \mathrm{~kg} \mathrm{ha}^{-1}$ as compared to finger millet + field bean (indeterminate type) intercropping system in 8:2 row ratio (3731 $\mathrm{kg} \mathrm{ha}^{-1}$ ) and sole crop of finger millet (2589 $\mathrm{kg} \mathrm{ha}^{-1}$ ).

Padhi et al., (2010) recorded that pigeon pea seed equivalent yield of all intercropping systems was significantly superior to their respective sole crop yields at both the row ratios. 14 per cent increase in grain yield of finger millet was observed at 2:8 row ratio while sowing at 2:4 row ratio recorded 15 per cent higher PSEY than the former row ratio due to 77 per cent increase in seed yield of pigeon pea in this row ratio. Jakhar et al., (2015) studied the strip combination equivalent yield of dominating crop. Among the different ratio of strip cropping, 4:6 row ratio gave higher FMEY along the years (2011-13). Strip ratio 6:4 gave 57, 44 and 59 per cent higher yield than sole finger millet in the year 2011, 2012 and 2013, respectively.

\section{Aggressivity}

Aggressivity (-2.44) of finger millet was negative and those of legume (2.44) was positive indicating finger millet a dominated species and legumes as dominant species (Maitra et al., 2002). Sarkar and Pal (2004) at Kolkata recorded Aggressivity (A) factor for rice which was only aggressive under 2:2 row ratio with both groundnut and pigeon pea than the ratio $2: 1,4: 1,6: 1,4: 2$ and $6: 2$, respectively. At New Delhi, Ahlawat et al., (2005) reported that aggressivity of chick pea 
was negative in all the intercropping systems. The aggressivity (A) of Indian mustard increased with increasing row ratio of chick pea + Indian mustard from $2: 1$ to $4: 1$, this increase was noticed in chick pea + barley only up to 3:1 row ratio. In chick pea + linseed intercropping system, linseed aggressivity decreased with increasing row ratio from 2:1 to 4:1. Mahale (2006) at Dapoli recorded that aggressivity (A) index was maximum in sesame + groundnut in 1:3 ratio with $0 \mathrm{~kg} \mathrm{~S} \mathrm{ha}^{-1}$ in case of sesame over all the treatment combinations. Aggressivity index of groundnut was negative indicating the dominance of sesame in intercropping system. Sharma et al., (2006) at Plampur (HP) found that the negative aggressivity (A) of intercrop except rajma with cabbage and cauliflower in all the arrangement indicated poor competitiveness of intercrop than the vegetable which had positive aggressivity (A) in a cabbage + French bean, potato + rajma, potato + French bean, tomato + rajma tomato + French bean. Padhi et al., 2010 at Agriculture Research Station Berhamapur (Orissa) recorded that highest aggressivity (A) in UPAS- 120 sown at 2:4 row ratio than TTB- 7 sown at 2:8 row ratio. Jakhar et al., (2015) studied the performance of finger millet and groundnut based strip cropping in ratio $6: 4,8: 4,10: 4$ and 12:4. The aggressivity (A) values for the entire strip cropping ratio were negative which indicated that finger millet have shown dominance over groundnut. Dominance was the lowest in 10:4 row ratio.

\section{Relative crowding coefficient}

Maitra et al., (2000) worked out Relative crowding coefficient for different intercropping systems and found that intercropping pigeon pea with finger millet had higher yield advantage (49.85) than finger millet + green gram (5.81), finger millet + groundnut (9.16), finger millet + soybean
(6.40). Sarkar and Pal (2004) from Kolkata reported the RCC values of rice which were greater than 1 , indicating that rice gave more yield than expected. The crowding coefficient indicated that it was advantageous to grow rice with groundnut at $2: 1,4: 1$ and $6: 1$ ratio and pigeon pea at 2:1, 4:1 and 6:1 ratio, which gave higher values than unity. Ahlawat et al., (2005) from New Delhi reported that RCC was higher in 2:1 row ratio of chick pea + barley and 4:1 row ratio of chick pea + linseed than other treatments. Sharma et al., (2006) at Palampur reported the highest relative crowding coefficient that was noticed in cauliflower + French bean ratio showing the highest yield advantage than other treatment.

\section{Competitive Ratio (CR)}

Jakhar et al., (2015) in strip combination of finger millet and groundnut 6:4 row proportion recorded that higher value (1.33) of $\mathrm{CR}$ for finger millet of its intercropping with groundnut which indicated that it was more competitive to groundnut because it had rapid initial growth rate leading to competition for resources with finger millet.

\section{Intercropping and nutrient uptake}

Mahadkar (1983) reported that mixture of finger millet + black gram had significantly higher total uptake of nitrogen i.e. $41 \mathrm{~kg} \mathrm{ha}^{-1}$ followed by green gram and mothbean combination. Geeta kumari and Shivshankar (1991) studied intercropping of ragi and soybean and observed that available $\mathrm{P}$ status of soil was more in intercropping plot and the uptake of $\mathrm{N}$ and $\mathrm{P}$ was more by pure crop of ragi and soybean due to competition for factors like light, space, moisture etc. in the intercropping system. Tomar et al., (1997) studied the response of wheat based intercropping system to $\mathrm{N}$ fertilizer levels. Sole lentil recorded highest $\mathrm{N}$ uptake over the 
cropping system followed by chickpea. Application of $90 \mathrm{Kg} \mathrm{N} \mathrm{ha}{ }^{-1}$ recorded higher $\mathrm{N}$ uptake than 0,30 and $60 \mathrm{~kg} \mathrm{~N} \mathrm{ha-}$. Intercropping of pulses with cereals and other non-legume companion crops have certain in built advantage over pure cropping. Further they have recorded that, pulses leave 20 $25 \mathrm{~kg} \mathrm{ha}^{-1}$ of nitrogen in the soil at the time of harvest, which is utilized by the subsequent crop and tremendous leaf fall will form best source of organic matter (Velayutham and Somasundaram, 2000).

Jha et al., (2000) conducted a field experiment at Agricultural College Farm, Dholi, Bihar and concluded that uptake is a function of yield, naturally higher uptake was recorded where yield was higher due to increased application of fertilizer particularly Nitrogen.

Oberson et al., (2001) from a field experiment conducted at the Carimagua Research Station, Colombia on maize + soybean or rice + cowpea intercropping system observed that legume based cropping systems maintained higher organic and available P levels than non legumes in rotation. Greater turnover of roots and above ground litter in legume-based intercropping could provide steadier organic inputs and therefore, high $\mathrm{P}$ cycling and availability.

\section{Intercropping and monetary return}

Economics of particular intercropping system is supposed to be the most important aspect from the crop production point of view. Intercropping aims at maximum production and net return per unit of time and space. Though the yield of main crop was reduced due to inclusion of component crop in intercropping systems, higher monetary return was recorded by many research workers in India, which is attributed to the bonus obtained from component crop
Intercropping is a profitable practice under rainfed condition. Growing of two or more crops on the same piece of land having different rooting capacity exploit the available resources from the soil to the fullest extent. Thus, increasing the overall production and monetary returns (Aiyer, 1949).

Intercropping of finger millet with cowpea in 2:1 row ratio recorded higher net return (Rs $2648 \mathrm{ha}^{-1}$ ) than the sole crop of finger millet and in ratios of 3:1 and 6:1 row ratio, Reddy et al., (1983). Thorat et al., (1986) reported that sole crop of groundnut gave significantly higher net return of Rs 2617.50 ha $^{-1}$ over all the treatments except finger millet + groundnut intercropping in 1:1 proportion which recorded the maximum net return of Rs $1948.74 \mathrm{ha}^{-1}$ which was statistically at par with the net return given by $2: 1$ proportion of the same crop combination. This accounts additional increase of Rs $1383.50 \mathrm{ha}^{-1}$ and Rs $1296.13 \mathrm{ha}^{-1}$, respectively over the net return given by the sole crop of finger millet.

Finger millet + black gram intercropping in $1: 1,2: 1,3: 1$ proportion on area basis recorded maximum net return of Rs. 1715.96, 1562.11 and 1477.15 ha- $^{1}$ respectively, Mahadkar and Khanvilkar (1988), Jadhav et al., (1992) reported that intercropping of finger millet with urd bean and okra in 4:2 row proportion gave a maximum net return of Rs. 3,615 and $3,579 \mathrm{ha}^{-1}$ with a cost: benefit ratio of 2.21 and 1.45 , respectively. Higher gross return in finger millet + pigeon pea 8:2 intercropping system as compared to finger millet + field bean 8:2 intercropping system and sole crop of finger millet were reported by Shankarlingappa and Hegde (1992). Singh and Arya (1999) from Ranichauri (Uttaranchal) reported higher net return and $\mathrm{B}$ : $\mathrm{C}$ ratio under mixed cropping of finger millet + soybean (9:1 seed mixture) as compared to finger millet + rice bean mixed cropping system and sole crop of finger 
millet. Maitra et al., (2000) from Shriniketan (West Bengal) reported that intercropping of finger millet + pigeon pea and finger millet + groundnut at 4:1 row proportion recorded higher monetary net returns and benefit : cost ratio than finger millet + green gram, finger millet + soybean and sole finger millet. Chakraborty et al., (2002) conducted experiment to study the efficiency of biofertilizer on finger millet raising the level of nitrogen from 0 to $80 \mathrm{~kg} \mathrm{ha}^{-1}$. The highest total return was recorded by Azospirillium +80 kg N ha ${ }^{-1}$ (Rs 7893 ha $^{-1}$ ) which was more or less same with $80 \mathrm{~kg} \mathrm{~N} \mathrm{ha}^{-1}$ (Rs $\left.7720 \mathrm{ha}^{-1}\right)$. From Hanumanamatti (Karnataka), Shashidhara (2000) reported higher net return (Rs. $7285 \mathrm{ha}^{-1}$ ) and B: C ratio (4.29) due to intercropping of finger millet with pigeon pea in $4: 2$ row ratio as compared to $3: 1$ and $5: 1$ row ratios (Rs. 5625 and $6672 \mathrm{ha}^{-1}$ of net returns and 3.24 and 3.99 B:C ratio, respectively)

Net returns of Rs. $23277 \mathrm{ha}^{-1}$ and benefit: cost ratio 5.90 were recorded under strip cropping of finger millet + pigeon pea as compared to sole crop of finger millet Rs $14854 \mathrm{ha}^{-1}$ net return and $4.30 \mathrm{~B}: \mathrm{C}$ ratio, Ramamoorthy et al., (2003). Ved Prakash et al., (2005) at Almora (Uttaranchal) reported relay cropping of wheat in finger millet (transplanted) + pigeon pea (4:1) registered higher gross return (Rs. $58799 \mathrm{ha}^{-1}$ ), net return (Rs $23149 \mathrm{ha}^{-1}$ ) and benefit: cost ratio (1.65) compared to relay cropping of wheat in finger millet (drilled) + pigeon pea (4:1) was found to be the next best in terms of gross return (Rs $56274 \mathrm{ha}^{-1}$ ), net return (Rs $20274 \mathrm{ha}^{-1}$ ) and benefit: cost ratio (1.56). In intercropping system of pigeon pea (UPAS. 120) + finger millet (Bhairabi) was found to be the most economic followed by UPAS. $120+$ PR 202 with comparable net returns at 2:4 ratio (Padhi et al., 2010).
Murali et al., (2014) reported that intercropping of finger millet + pigeon pea (transplanted) with 4 week old seedling gave maximum net returns $\mathrm{Rs} 26,218$ ha $^{-1}$ with $\mathrm{B}: \mathrm{C}$ ratio 2.49 compared to finger millet + direct sown pigeon pea (Rs 4,974 to Rs $13,899 \mathrm{ha}^{-1}$ with B:C ratio of 1.37 to 2.02). Jakhar et al., (2015) from Odisha reported that strip cropping of finger millet + groundnut in different ratio resulted in to maximum net returns from 6:4 row ratio. B:C ratio (2.87) was highest as compared to all the treatments.

The literature on economics of intercropping system clearly indicated that finger millet based intercropping system accounted for higher economic returns than sole cropping. Among the intercropping systems, finger millet + pigeon pea / soybean / urd / bean / okra accounted for higher economic returns than other system of finger millet with field bean / cowpea / green gram.

\section{References}

Adikant Pradhan, A. Sao, D.P. Patel, S. K. Nag and S.C. Mukherjee (2015). Effect of establishment methods and nitrogen levels on finger millet. Ann. Agric. Research. New Series 36(1):107-113.

Ahlawat, I.P.S., Gangaiah, B. and Ompal Singh (2005). Production potential of chick pea based intercropping system under irrigated condition. Indian Journal of Agronomy, 50(1): 27-30.

Ayyangar, G.N.R and Ayyer (1942). Mixed cropping a review. Madras Agricultural Journal, 30: 3-13.

Ayyer, A.J.Y.N. (1963). Principle of crop Husbandry in India. Bangalore press, pp. 406.

Bandyopadhyay, S.K and R. De (1986). Plant growth and seed yield of sorghum when intercropped with legumes. J. Agric. Sci. (U.K), 107(3): 621-627. 
Brar, A.K. and Gautam, R.C (1991). Effect of biofertilizer and seed treatment in pearl millet and oil seed intercropping under dry land condition. Annals of Agricultural Research, 12(2): 142-150.

Chakraborty, T. D.K. Roy and G. Sunda (2002). Effect of fertilizers, rock phosphate and Azospirillum on growth and yield of finger millet Indian $J$. Agron., 36 (3): 192-195.

Chandel, A.S., K.N. Pandy and S.C. Saxena (1989). Symbiotic nitrogen fixation and nitrogen benefit by nodulated soybean (Glycine $\max$ (L.) Merrill) to interplanted crop in North India. Trop. Agric. Trininad, 66(1): 73-77.

Dalavi, N.D., Patil, V.G., Jadhav, A.S. and Harinarayana, G. (1993). Nitrogen economy through biofertilizer in pearl millet. J. Maharashtra Agric. Univ., 18(3): 466-467.

Das, K. and B. Guha (1996). Intercropping of rape seed with Niger under rainfed condition. Indian J. Agron., 41(4): 542545.

Deshmukh, G.N. (2007). Studies on effect of FYM, Lime, NP Fertilizers and Boron on yield, nutrient uptake and quality of nagli (Eleusine coracana G.) M.Sc. (Agri.) Thesis submitted to the Dr. B.S.K.K.V., Dapoli.

Dubey, O. P. and D. N. Shrivas (1997). Productivity and economics of kodomillet based intercropping system under rainfed condition. Indian $J$. Agron. 42(2): 224-227.

Francis, C.A. and G.H. Hiechel (1973). Efficacy of energy production in maize, bean and other mixed cropping systems. Agronomy abstracts, USA, pp. 72-73.

Girish, K.M. (2004). Studies on Finger millet (Eleusine coracana G.) based intercropping system. M.Sc. (Agri.) Thesis, U.A.S. Dharwad.

Gopalrao, P., Reddy, R. G. M., Reddy R. P. and Rao, A. M. (1986). Research note on the effect of shelter belts on response of finger millet to nitrogen. Andhra agric. J., 33(1): 78-79.

Gowda, B.K., Rajappa, M.G. and suresh, H.N. 1977. Determining optimum time of nitrogen application to rainfed ragi. Mysore J. Agric. Sci., 11(4): 329-332.

Ghosh, P.K (2004). Growth, yield competition and economics of groundnut/ cereals fodder intercropping system in the semi- arid tropics of India. Field Crops Research. 88(2/3): 227237.

Gowda, L.B.K., Ashok, E.G and Chandrappa, M. (1986). Agronomic investigation on small millets in Karnataka. SOUVENIR international workshop on small millet, The University of Agricultural Science, Banglore. pp. 19.

Ipsita Kar and Vishram Ram (2015) Performance of baby corn + groundnut intercropping system under the influence of residual green manure and phosphorus. Bioinfolet, 12 (1-B): 206208

Itnal, C.J., V.P. Nagalikar, B.S Lingaraju and P. Basavaraj (1994). Intercropping pigeon pea with pearl millet in North Eastern Dry Zone of Karnataka. Karnataka J. Agric. Sci., 7(1):6-9.

Jadhav, A.S Kalbhor, P.M. and Deshpande, S.V. (1983). Intercropping of moong and groundnut in sorghum with different planting patterns under rainfed conditions. J. Maharashtra Agric. Univ., 8(1): 63-65.

Jadhav, S. N., A. S. Bal and U. A. Gadre (1992). Intercropping urdbean and okra in finger millet is remunerative in Konkan. Indian farming.

Jagannath, M. K. and Sunderaral, N. (1987). Productivity equivalent ratio and statistical testing of its advantages in intercropping. JInd. Soc. Ag. Statistics. 49: 289-300. 
Jakhar, P., Adhikary, P. P., Naik, B. S. and Madhu, M. (2015). Finger millet groundnut strip cropping for enhanced productivity and resource conservation in upland of Eastern Ghats of Odisha. Indian J. Agron., 60 (3):365-371.

Jasbir Singh and O.V.S. Thenua (2014) growth and yield of soybean as influenced by maize + soybean intercropping system and nitrogen levels. Ann. Agric. Research. New Series 35(1): 32-36.

Jat, P. C., S. S. Rathore, and R. K. Sharma (2014). Effect of integrated nitrogen management and intercropping system on yield attributes and yield of maize. Indian Journal of Hill Farming,27(1): 52-56.

Jat, R.L., Gaur B.L., Kumar Suresh and Kulhari R.K. (1999). Effect of weed management, fertilizers and Rhizobium inoculation on growth, yield and yield attributes of maize and soybean under maize + soybean intercropping system. Indian J. Agron. 44(1): 30-35.

Jena, B.K., H. Patro and S.C. Panda (2000). Intercropping in finger millet. Environment and Ecologica, 18(2): 463-464

Kadrekar, S.B and Bhosale, R.J.1998 Nitrogen and phosphorus response of finger millet under rainfed conditions. Indian J. Agron., 26(1): 103-104.

Kalra, G.S. and Gangwar, B. (1980). Economics of intercropping of different legumes with maize at different level of nitrogen under rainfed conditions. Indian J Agron.25: 181-185

Karanam Navya Jyothi. Sumathi V. and Sunitha N. (2016) Productivity, nutrient balance and profitability of foxtail millet varieties as influenced by levels of nitrogen. Journal of Agriculture and Veterinary Science, 9(4): 18-22.
Lal, R.B. and S. Ray (1976). Economics of crop production of different intensities. Indian J. Agric. Sci., 46: 93-96

Lingegouda, B.K., Santathaveerbadrah, S.S., Inamdar, Prithviraj and Krishnamurthy, K.C. (9172). Studies of mixed cropping of groundnut and hybrid sorghum. Ind. J. Agron. 17(1): 27-29.

Mahadkar U.V. (1983). Study of mixed cropping in Kharifnagli with some important pulses under high rainfall condition of Konkan. M.Sc. (Agri.) Thesis, B.S.K.K.V., Dapoli, Maharashtra.

Mahale, M.M. (2006). Performance of sesame + Groundnut intercropping system under different levels of sulphur. M.Sc. (Agri.) Thesis, B.S.K.K.V., Dapoli, Maharashtra.

Mandimba, G.R., Galandzou, C. and Guenguie, N. (1998). Effect of plant population densities on the growth of maize and groundnut intercropping system. International J.of Tropical Agriculture. 16(1-4): 33-50.

Mc Gillchrist, C.A and B.R. Trenbatn (1971). A revised analysis of plant competition experiment. Biometrics, 27: 659-671

Mehata, O. P., Bhola, A.L., Tomer, D.P.S. and Yadav, T.P (1985). Studies on intercropping of groundnut. J. Oilseed Res. 2: 45-49.

Mitra S, Gosh D. C., Sunda G. and Jana P.K (2001). Performance of intercropping legumes in finger millet (Eleusine coracana) at varying fertility levels. Indian J. Agronomy 46(1): 38-44.

Mohapatra, A.K. and J. Haldar (1998). Intercropping of soybean and rice bean with rice and ragi under different planting pattern. Annals of Agri. Research., 19(1): 114-115.

More, V.G. (1990). Study of intercropping of some oilseed and pulse crop in kharif finger millet under high rainfall 
condition of Konkan. M.Sc. Agri. Thesis, B.S.K.K.V., Dapoli, Maharashtra.

Murali K. T. Sheshadri and M. Byregowda (2014) Effect of pigeonpea transplanting on growth, yield and economics in sole and finger millet intercropping system under late sown condition. Journal of Food Legume, 27(1): 28-31.

Naiyar Ali and Ahmad S. (2004) Response of finger millet varieties to nitrogen levels under rainfed condition. Journal of Research, Birsa Agricultural University, 16(1): 51-54.

Obserson, A. Friesen, D K., Rao I.M, Buhler, S., and Frossard E. (2001). Phosphorus transformation in an oxisol under contrasting land- use systems: the role of the soil microbial biomass. Plant and Soil, 237:197-210

Obilana, A.B., and E. Manyasa. 2002. Finger millet. In: Belton P and J Taylor (eds) Pseudocereals and Less Common Cereals: Grain Properties and Utilization Potential. Springer -Verlag Berlin Heidelberg New York. pp. 177214.

Pawer, H.K., D. N. Dorge and D. B Naik. 1985. Nutrient uptake in intercropping system of sorghum and benglagram under dryland condition. $J$ Maharashtra Agric. Univ.11 (1): 6-8.

Padhi A. K., Panigrahi R. K. and Jena B. K. (2010) Effect of planting geometry and duration of intercrops on performance of Pigeonpea - finger millet intercropping system. Indian Journal Agric. Research 44(1):43-47.

Parida, D., V.N. Dikshit; D. satpathy and P. K. Amhapatra (1989). Genotype compatibility study in pigeon pea + finger millet intercropping system. Indian J. of Dryland Agriculture Research and Development, 4(1): 5055.
Pillai M.R., Shanmuga; Sondram Govindrajan, M. and Manamohan, S. L. (1957). Mixed cropping trials with Finger millet cotton and Groundnut. Madras Agric. J., 44(1):131-140.

Pradhan, A.C. and Ghosh, D.C. (1988). Mixed cropping of finger millet with black gram and green gram Indian J. of Agronomy, 33(3): 318-320.

Raghavalu, P. and K. Rama Rao (1994). Studies on setaria + pigeonpea intercropping system in scare rainfall zone of Andhra Pradesh. Mysore J. of Agril. Sci., 28: 314-318.

Rajendra Prasad. 2012. Text book of field crops production, food grain crops. Vol.I. Indian council of Agricultural Research, New Delhi. Second edn.

Rajshekhara, B.G., Jagannath, M.K. and Krishnamurthy, K. 1971 Factors governing Response of rainfed ragi to nitrogenous fertilizers. Indian J. Agron., 16(1):54-59.

Ram, S.N. and Bhagwan Singh (2003). Physiological growth parameters, forage yield and $\mathrm{N}$ uptake of sorghum as influenced with legume intercropping, harvesting time and nitrogen level. Indian Journal of Agronomy, 48(1):3841.

Ramamoorthy, K., A. Christopher Laurduras, S. Alagudurai, O.S. Kanaasamy, and V. Murugappan (2004). Intercropping pigeonpea in finger millet on productivity and soil fertility under rainfed condition. Indian Journal of Agronomy, 46 (1): 28-30.

Ramamoorthy, K., A. Christopher Laurduras, S. Radhamani, N. Sankaran, and T.M. Thiyaghorasan (2003). Effect of intercropping of field bean on productivity of finger millet under rainfed condition. Crop Research, 26(3): 515-518.

Ramasamy, K., Christopher, A. and Lourduraj (2002). Effect of intercrop and nutrients 
on yield attributes and yield of rainfed pearl millet. Madras Agric. J., 89(1012): 631-633.

Ramaswami, K.P. and Subramanian, S. 1973 effect of irrigation and nitrogen levels on nutrient contents in ragi. Madras Agric. J., 65(8):502-504

Reddy, M.S.., Floyd, C.M. and R.W. Willey (1980). Groundnut in intercropping system. In: Proceeding of International workshop on groundnut, India 13-17 October, 1980, pp. 133-142.

Reddy, V.C., B.K. Linga Gowda, M.G. Rajappa, and A.S Kumar Swamy (1983). Intercropping of finger millet under rainfed condition. Mysore Journal of Agricultural Sciences,17: 57.

Roy, R.P., Sharma, H.M and Thakur, H.C (1981). Studies on intercropping in long Duration pigeonpea on sandy loam soil of north Bihar. Indian J. Agron., 26 (1): $77-82$

Sahu, B.N. (1965). Response of different crops (Ragi and Rice) to fertilizer application in different soils. Journal of Indian Society of Soil Science, 13: 241249.

Sarangi, S. K., Mohanty B. P. and Chaudhary S. S. (2002) Effect of planting geometry and nitrogen levels on yield of Niger finger millet intercropping system in rainfed upland. Agricultural science digest, 22(2): 136-137.

Sarkar, R.K and P.K Pal (2004). Effect of intercropping rice with groundnut and pigeon pea under different roe orientation on rainfed upland. Indian Journal of Agronomy, 49(3): 147-150.

Shankaralingappa, B.C. and B.R. Hegde (1992). Intercropping studies in finger millet with pigeon pea and field bean. Mysore J. Agric. Sci., 26: 248-253.

Shankaralingappa, B.G. and B.G Rajashekara (1992). Intercropping of legume in finger millet genotype. Farming System, 8(1-2):24-29

Sharma Akhilesh; J.J. Sharma; M.C Rana and Sonia Sood (2006). Evaluation of Phaseolus vulgaris as intercrop with vegetable for enhancing productivity system and profitability under high hill dry temperate condition of NorthWestern Himalayas. Indian Journal of Agricultural Science, 76(1): 29-32.

Shashidhara, G.B., R. Basavarala and V.B. Nadagouda (2000). Studies on pigeon pea intercropping system in small millet under shallow red soil. Karnataka Journal of Agricultural Science, 13(1): 7-10.

Shivakumar, M.V.K. and S.M. Virmani (1980). Growth and Resources use of maize. Pigeon pea and maize/pigeon pea intercrop in an operational research water shed. Expt. Agric., 16(4): 377386.

Shivkumar, B.G. and Y.H. Yadahalli (1996). Performance of finger millet genotype under late sown dry land condition as influenced by intercrops and intercropping system. Indian J. Agric. Res., 30(3): 173-178.

Siddheswaran, K. C. Ramasamy and Y.B. Morachan (1987). Light interception and dry matter production under finger millet based cropping system. Madras Agric. J., 74(8-9): 413-417

Sing, R.V. and M.P.S. Arya (1995). Nitrogen requirement of barnyard millet + pulse intercropping system. Indian Journal of Agronomy, 46(2): 172-175.

Sing, R.V. and M.P.S. Arya (1999). Nitrogen requirement of finger millet + pulse intercropping system. Indian Journal of Agronomy, 44(13): 47-50.

Singh G. P., Singh P. L. and Panwar A. S. (2011) Response of groundnut to biofertilizer, organic and inorganic sources of nutrient in north east India. Legume Res., 34(3): 196-201. 
Subba Rao, N.J., Lakshmikumari, M., Tilak, K.V.B.R. and Singh, C.S (1983). Field response of finger millet to inoculation with Azospirillum brasilense. Curr. Sci., 52: 9

Subbiah, B.V. and Asija, G.L. (1956). A rapid procedure for the estimation of available $\mathrm{N}$ in soil. Curr. Sci. 25(8): 259-260.

Thorat, S.T., S.A. Chavan and S.N. Jadhav (1986). Intercropping of groundnut and red gram with ragi in Konkan. J.Mah. Agric. Univ., 11(3): 357-358.

Upadhaya, B.P. (2006). Climate and agriculture. (Online). Available: http://www.gorkhaptra.org.np/index.php (Retrieved on $9^{\text {th }}$ Nov, 2005).

Willey, R. W., and D.S.O Osiru (1972). Studies on mixture of maize and bean with particular reference to plant population. J. Agric. Sci. (Comb)., 79: 519-527.

\section{How to cite this article:}

Bhagat, S.B., A.V. Dahiphale, N.V. Mhaskar, D.G. Jondhale and Puri, M.C. 2019. Finger Millet (Eleusine coracana G.) based Intercropping for Food Security in Konkan Region -A Review. Int.J.Curr.Microbiol.App.Sci. 8(01): 3065-3077. doi: https://doi.org/10.20546/ijcmas.2019.801.327 